\title{
THE EFFECTS OF CORTISONE AND HYDROCORTISONE ON WATER DIURESIS AND RENAL FUNCTION IN MAN
}

\author{
BY LAWRENCE G. RAISZ,1 WILLIAM F. MCNEELY, LAWRENCE SAXON, AND \\ JACK D. ROSENBAUM \\ (From The Medical Service and Research Laboratory, Boston Veterans Administration Hospital, \\ the Department of Medicine, Boston University School of Medicine, and the \\ Department of Medicine, Tufts University School of Medicine, \\ Boston, Mass.)
}

(Submitted for publication November 5, 1956; accepted February 7, 1957)

The deficient diuretic response to water which is characteristic of patients with adrenal insufficiency can be rapidly corrected by the administration of cortisone (1-3). The mechanism of the defective diuresis and the precise nature of the response to hormonal replacement have not been established. A number of observations, chiefly in experimental animals, have suggested that administration of various adrenocortical preparations in large "pharmacologic" doses also influences water diuresis in the normal organism (4). However, no systematic study of the latter effect has been made in man. The present report describes the effects of large doses of cortisone and hydrocortisone on water diuresis, renal solute excretion, glomerular filtration rate, and effective renal plasma flow in man. Striking augmentation of the maximal rates of urine flow observed during maintained water loading was a regular occurrence. The steroids studied appear to have a specific influence upon water reabsorption by the renal tubules, an action which can be separated from their effect on renal hemodynamics.

\section{MATERIALS AND METHODS}

The subjects were adult male patients free from cardiovascular, renal and endocrine disease. Three sets of studies concerning water diuresis were carried out.

Group I-A-Intermittent studies during prolonged intramuscular administration of cortisone. In these experiments creatinine clearance was measured, but not inulin or para-aminohippurate clearances. Urinary total solute concentration was calculated from determined cations and urea; freezing point determinations were not made.

\footnotetext{
1 Present address: Veterans Administration Hospital, Syracuse, New York.
}

Group $I-B$-Serial studies at intervals of one to three days during prolonged oral cortisone and hydrocortisone administration. Clearances of inulin and para-aminohippurate, as well as of creatinine, were determined. Urinary osmolality was measured cryoscopically.

Group II-The acute response to intravenous infusion of hydrocortisone during water diuresis. Renal clearances and urinary total solute concentrations were measured as in I-B.

Details of experimental procedure will be given together with the results in each group.

\section{Chemical methods and calculations}

Urine and serum were analyzed for sodium, potassium, chloride and creatinine by methods previously described (5). Serum creatinine was determined after adsorption on Lloyd's reagent (6). Total solute concentration in urine and serum was measured by freezing point depression using a Fiske osmometer (Advanced Instruments, Inc., Needham, Mass.). Duplicate samples checked within 2 per cent. Results are recorded for simplicity as "mOsm. per L." although they actually are determinations of osmolal concentrations, i.e., milli-osmols per kilogram of serum or urine water. Glomerular filtration rate was measured with inulin employing an anthrone method (7). Serum recoveries performed with each set of analyses averaged 98.2 per cent with a range of 94.7 per cent to 105.7 per cent. No correction was applied for the recovery error. Effective renal plasma flow was measured with para-aminohippurate (8). Clearance values were not corrected for the concentration of plasma water. Free water clearance $\left(\mathrm{C}_{\mathrm{B}} \mathrm{O}\right)$ was calculated as the difference between urine flow (V) and osmolal clearance $\left(\mathrm{C}_{0 \mathrm{sm}}\right)$ as follows:

$$
\mathrm{C}_{\mathrm{H}_{2} \mathrm{O}}=\mathrm{V}-\frac{\mathrm{U}_{\mathrm{Oam}} \mathrm{V}}{\mathrm{P}_{\mathrm{Oem}}}
$$

Only one urine sample and one blood sample were analyzed for urea and ammonia (9) in each of the serial experiments during oral administration of steroid (Group I-B); whereas in three of the four studies of the effects of hydrocortisone infusion (Group II) these constituents were measured during successive periods throughout the experiment. 
TABLE I

Intermittent observations during prolonged intramuscular administration of cortisone*

\begin{tabular}{|c|c|c|c|c|c|c|c|c|c|c|c|}
\hline $\begin{array}{c}\text { Patient, age, } \\
\text { diagnosis, and } \\
\text { duration of treatment }\end{array}$ & $\begin{array}{c}\text { Cortisone } \\
\text { dosef }\end{array}$ & $\begin{array}{l}\text { Day of } \\
\text { study }\end{array}$ & Diet & $\begin{array}{c}\text { Days } \\
\text { on diet }\end{array}$ & Weight & $\begin{array}{l}\text { Urine } \\
\text { flow }\end{array}$ & $\begin{array}{c}\text { Sodium } \\
\text { excretion }\end{array}$ & $\begin{array}{c}\text { Potassium } \\
\text { excretion }\end{array}$ & $\begin{array}{c}\text { Urea } \\
\text { excretion }\end{array}$ & $\begin{array}{l}\text { Creat. } \\
\text { clear. }\end{array}$ & $\begin{array}{l}\text { Calc. } \\
\text { total } \\
\text { solute } \\
\text { conc. }\end{array}$ \\
\hline $\begin{array}{l}\text { A. D. } 27 \text { yrs. } \\
\text { Neurodermatitis } \\
\text { 32-day course }\end{array}$ & $\begin{array}{c}\text { mg./day } \\
200 \\
200\end{array}$ & $\begin{array}{r}-14 \\
14 \\
21 \\
+10\end{array}$ & $\begin{array}{c}\text { Rice } \\
\text { Rice } \\
\text { Rice } \\
\text { Ad lib. }\end{array}$ & $\begin{array}{r}3 \\
3 \\
10 \\
10\end{array}$ & $\begin{array}{c}K \boldsymbol{K g} . \\
70.3 \\
73.1 \\
71.0 \\
74.2\end{array}$ & $\begin{array}{c}\text { ml./min. } \\
10.0 \\
32.1 \\
24.2 \\
17.9\end{array}$ & $\begin{array}{c}\mu E q . / \min . \\
10 \\
150 \\
57 \\
294\end{array}$ & $\begin{array}{c}\mu E q . / \min . \\
72 \\
69 \\
35 \\
104\end{array}$ & $\begin{array}{c}\text { mmol./min. } \\
203 \\
380 \\
398 \\
217\end{array}$ & $\begin{array}{c}\text { ml./min. } \\
139 \\
175 \\
160 \\
146\end{array}$ & $\begin{array}{c}\text { mOsm./L } \\
378 \\
28 \\
30 \\
56\end{array}$ \\
\hline $\begin{array}{l}\text { A.S. } 24 \text { yrs. } \\
\text { Allergic rhinitis } \\
\text { 33-day course }\end{array}$ & $\begin{array}{l}200 \\
200\end{array}$ & $\begin{array}{r}-1 \\
19 \\
26 \\
+\quad 6\end{array}$ & $\begin{array}{c}\text { Rice } \\
\text { Rice } \\
\text { Ad lib. } \\
\text { Ad lib. }\end{array}$ & $\begin{array}{l}3 \\
5 \\
1 \\
2\end{array}$ & $\begin{array}{l}63.2 \\
66.1 \\
71.1 \\
75.3\end{array}$ & $\begin{array}{r}6.7 \\
15.3 \\
24.0 \\
16.5\end{array}$ & $\begin{array}{r}2 \\
12 \\
149 \\
86\end{array}$ & $\begin{array}{r}99 \\
82 \\
66 \\
101\end{array}$ & $\begin{array}{l}195 \\
278 \\
322 \\
352\end{array}$ & $\begin{array}{l}118 \\
147 \\
158 \\
155\end{array}$ & $\begin{array}{l}62 \\
32 \\
31 \\
45\end{array}$ \\
\hline $\begin{array}{c}\text { H.S. } \\
\text { Asthmatic bronchitis } \\
\text { 45-day course }\end{array}$ & $\begin{array}{l}200 \\
200 \\
200\end{array}$ & $\begin{array}{r}-1 \\
12 \\
29 \\
33 \\
+17\end{array}$ & $\begin{array}{c}\text { Low salt } \\
\text { Low salt } \\
\text { Ad lib. } \\
\text { Rice } \\
\text { Ad lib. }\end{array}$ & $\begin{array}{r}11 \\
24 \\
3 \\
3 \\
17\end{array}$ & $\begin{array}{l}58.5 \\
59.3 \\
60.2 \\
57.7 \\
57.9\end{array}$ & $\begin{array}{l}17.2 \\
21.6 \\
33.0 \\
27.8 \\
21.8\end{array}$ & $\begin{array}{r}18 \\
21 \\
209 \\
122 \\
92\end{array}$ & $\begin{array}{l}77 \\
50 \\
72 \\
79 \\
78\end{array}$ & $\begin{array}{l}259 \\
261 \\
380 \\
176 \\
250\end{array}$ & $\begin{array}{l}122 \\
129 \\
180 \\
154 \\
147\end{array}$ & $\begin{array}{l}32 \\
25 \\
32 \\
24 \\
30\end{array}$ \\
\hline $\begin{array}{l}\text { B. H. } 23 \text { yrs. } \\
\text { Rheumatoid arthritis } \\
\text { 14-day course }\end{array}$ & 500 & $\begin{array}{r}-1 \\
14 \\
+6\end{array}$ & $\begin{array}{c}\text { Ad lib. } \\
\text { Low salt } \\
-\|\end{array}$ & $\begin{array}{l}-1 \| \\
6\end{array}$ & $\begin{array}{l}60.5 \\
59.2 \\
58.4\end{array}$ & $\begin{array}{l}13.3 \\
24.8 \\
16.0\end{array}$ & $\begin{array}{l}58 \\
87 \\
26\end{array}$ & $\begin{array}{l}75 \\
55 \\
45\end{array}$ & & $\begin{array}{l}159 \\
146 \\
119\end{array}$ & \\
\hline $\begin{array}{l}\text { W. H. } 51 \text { yrs. } \\
\text { Rheumatoid arthritis } \\
\text { 32-day course }\end{array}$ & $\begin{array}{l}500 \\
500\end{array}$ & $\begin{array}{r}-1 \\
4 \\
15 \\
+10 \\
+17\end{array}$ & $\begin{array}{l}\text { Low salt } \\
\text { Low salt } \\
\text { Low salt } \\
\text { Low salt } \\
\text { Low salt }\end{array}$ & $\begin{array}{r}7 \\
13 \\
22 \\
49 \\
56\end{array}$ & $\begin{array}{l}61.4 \\
62.2 \\
65.5 \\
65.6 \\
63.3\end{array}$ & $\begin{array}{r}7.7 \\
10.8 \\
20.6 \\
19.0 \\
10.9\end{array}$ & $\begin{array}{r}28 \\
2 \\
36 \\
229 \\
25\end{array}$ & $\begin{array}{l}56 \\
55 \\
63 \\
38 \\
83\end{array}$ & & $\begin{array}{r}113 \\
116 \\
132 \\
98 \\
113\end{array}$ & \\
\hline $\begin{array}{c}\text { G.S. } \quad 37 \text { yrs. } \\
\text { Rheumatoid arthritis } \\
\text { 14-day course }\end{array}$ & $\begin{array}{l}500 \\
500 \\
500\end{array}$ & $\begin{array}{r}-2 \\
-\quad 1 \\
3 \\
9 \\
13 \\
+19\end{array}$ & $\begin{array}{l}\text { High salt } \\
\text { High salt } \\
\text { High salt } \\
\text { High salt } \\
\text { High salt } \\
\text { High salt }\end{array}$ & $\begin{array}{r}2 \\
3 \\
6 \\
12 \\
16 \\
33\end{array}$ & $\begin{array}{l}54.6 \\
54.6 \\
54.6 \\
59.8 \\
61.6 \\
54.9\end{array}$ & $\begin{array}{l}11.5 \\
13.0 \\
16.0 \\
21.1 \\
30.2 \\
13.3\end{array}$ & $\begin{array}{r}85 \\
126 \\
17 \\
29 \\
307 \\
51\end{array}$ & $\begin{array}{l}\mathbf{5 5} \\
\mathbf{5 3} \\
\mathbf{6 1} \\
\mathbf{5 4} \\
\mathbf{7 7} \\
\mathbf{7 9}\end{array}$ & & $\begin{array}{l}121 \\
109 \\
117 \\
139 \\
169 \\
107\end{array}$ & \\
\hline
\end{tabular}

* Values given represent the mean renal excretion rate for 90 to 180 minutes of sustained water diuresis.

† Intramuscular cortisone acetate either $125 \mathrm{mg}$. q.6.h. or $100 \mathrm{mg}$. q.12.h.

$\ddagger(-)$ and $(+)$ sign indicate pre- and post-cortisone control days, respectively.

Italicized values are calculated as $2(\mathrm{Na}+\mathrm{K})+$ urea.

$\|$ Patient had been eating well on an unrestricted diet prior to cortisone therapy; after therapy he was offered the same diet but ate very poorly.

\section{EXPERIMENTAL PROCEDURE AND RESULTS}

Group I. Intermittent studies during prolonged intramuscular cortisone administration (Table I) ${ }^{2}$

Six male patients were studied at various intervals before, during, and after the administration of cortisone acetate intramuscularly in doses of $125 \mathrm{mg}$. every six hours or $100 \mathrm{mg}$. every twelve hours for 14 to 45 days. The following diets were employed :

2 A preliminary report of this work appeared in the Proceedings of the 43rd Annual Meeting of the Society for Clinical Investigation, Atlantic City, New Jersey, May, 1951 (10).
1) Rice Diet-Containing less than $15 \mathrm{mEq}$. of sodium per day.

2) Low Salt Diet-Containing 15 to $35 \mathrm{mEq}$. of sodium per day.

3) Ad libitum Diet-Sodium intake approximately 130 to $200 \mathrm{mEq}$. per day.

4) High Salt Diet-Low salt diet plus $43 \mathrm{mEq}$. of sodium every six hours as a 0.45 per cent solution of $\mathrm{NaCl}$; total intake 187 to $207 \mathrm{mEq}$. per day.

About one hour after a light breakfast the subjects, who remained seated except to void, were given an oral water load of $20 \mathrm{ml}$. per kilogram of body weight. Urine flow, electrolyte excretion, and creatinine clearance were measured during one and one-half to three hours of sustained diuresis, 
with replacement of water based upon serial weighings of the subject. Urea excretion was determined in three of the six subjects. Total osmolality of the urine was not measured cryoscopically, but when urea and ammonia were determined total urinary solute was calculated as the sum: $2(\mathrm{Na}+$ $\left.\mathrm{K}+\mathrm{NH}_{4}\right)+$ urea. $^{3}$

The rate of urine flow during maintained water diuresis rose in each case while cortisone was being given. The flow rate on the third and fourth day of steroid administration in the two subjects tested on these days had increased by 3.0 to 3.1 $\mathrm{ml}$. per minute. The increase after the eighth day ranged from 4.4 to $22.1 \mathrm{ml}$. per minute. Augmentation of flow took place irrespective of change in sodium excretion. However, in the four subjects who were studied on more than one occasion after the eighth day of cortisone administration, the magnitude of increase appeared to vary with the contemporaneous rate of sodium excretion. The changes in natriuresis could in turn be related to dietary salt intake except in G.S. This subject received the high salt diet throughout. $\mathrm{He}$ retained sodium and gained weight during the first ten days of steroid administration, while his maximal urine flow almost doubled. Thereafter, with cortisone intake constant, there was little further weight gain, sodium excretion rose strikingly and concomitantly a further marked rise in flow was demonstrated. Although weight gain was the rule, subject B.H., whose urine flow increased strikingly, lost $1.3 \mathrm{Kg}$. Creatinine clearance generally increased during cortisone administration but changes in urine flow and creatinine clearance were sometimes dissociated. For ex-

3 In 36 urine samples, obtained during other studies of water diuresis, which varied between 33 and $72 \mathrm{mOsm}$. per L. measured cryoscopically, total solute concentration was compared with the sum: $2\left(\mathrm{Na}+\mathrm{K}+\mathrm{NH}_{4}\right)+$ urea. The calculated values were equally distributed above and below the cryoscopic values with an average difference of 2.0 $\mathrm{mOsm}$. per $\mathrm{L}$. It is recognized that twice the concentration of the univalent cations exceeds the osmolal concentration provided by these electrolytes owing to incomplete dissociation and to the presence of anions of valence greater than one. However, the osmolal concentration of undetermined solutes must approximate this discrepancy in magnitude to explain the good agreement between calculated and cryoscopically determined values. Similar good agreement has been obtained in dilute urine samples which do not contain inulin or para-aminohippurate. ample, in patient A.S. urine flow fell from 24 to $16.5 \mathrm{ml}$. per minute when cortisone was discontinued, but creatinine clearance did not change. In the three subjects whose urea excretion was measured, calculated urinary osmolality during cortisone administration was lower than the control in six of seven comparisons. In one of the studies of H.S., urine solute concentration was the same as before steroid administration, but salt had been added to the diet and total solute excretion had risen from 540 to $1060 \mu \mathrm{Eq}$. per min.

\section{Group I-B. Serial studies at intervals of one to three days during prolonged oral cortisone and hydrocortisone administration (Tables II and III; Figures 1 and 2)}

Three men, hospitalized because of chronic skin conditions, but otherwise healthy, were studied before, during and after a two-week period of oral administration of cortisone acetate or hydrocortisone. Their basic diet provided $10 \mathrm{mEq}$. of sodium and 2,000 calories, but they were allowed to eat extra portions from this diet as desired so that in some instances sodium intake might have been as much as $25 \mathrm{mEq}$. per day. The salt-poor diet was begun three days before the first experiment, and the subjects were given water loads on several occasions before the experiments were actually performed in order to accustom them to the procedure.

The schedule of individual experiments with the dose of hormone administered to each of the three subjects is given in Table II. Equally divided doses were taken at 6-hour intervals. After the high doses of hormone were discontinued, A.B. received a daily "maintenance" dose of $37.5 \mathrm{mg}$. of cortisone for four days and R.H. received 20 $\mathrm{mg}$. of hydrocortisone daily for three days. Each experiment was begun about one-half hour after a light breakfast and two hours after the last dose of steroid. The subject was weighed and a venous blood sample obtained. After a suitable priming dose, an intravenous infusion of inulin and para-aminohippurate in isotonic saline was given at the rate of $0.6 \mathrm{ml}$. per min. The subject then drank $20 \mathrm{ml}$. of water per kilogram of body weight. This load was maintained after each voiding by having the subject drink an amount of water equal to the volume of urine excreted plus 
L. G. RAISZ, W. F. MCNEELY, L. SAXON, AND J. D. ROSENBAUM

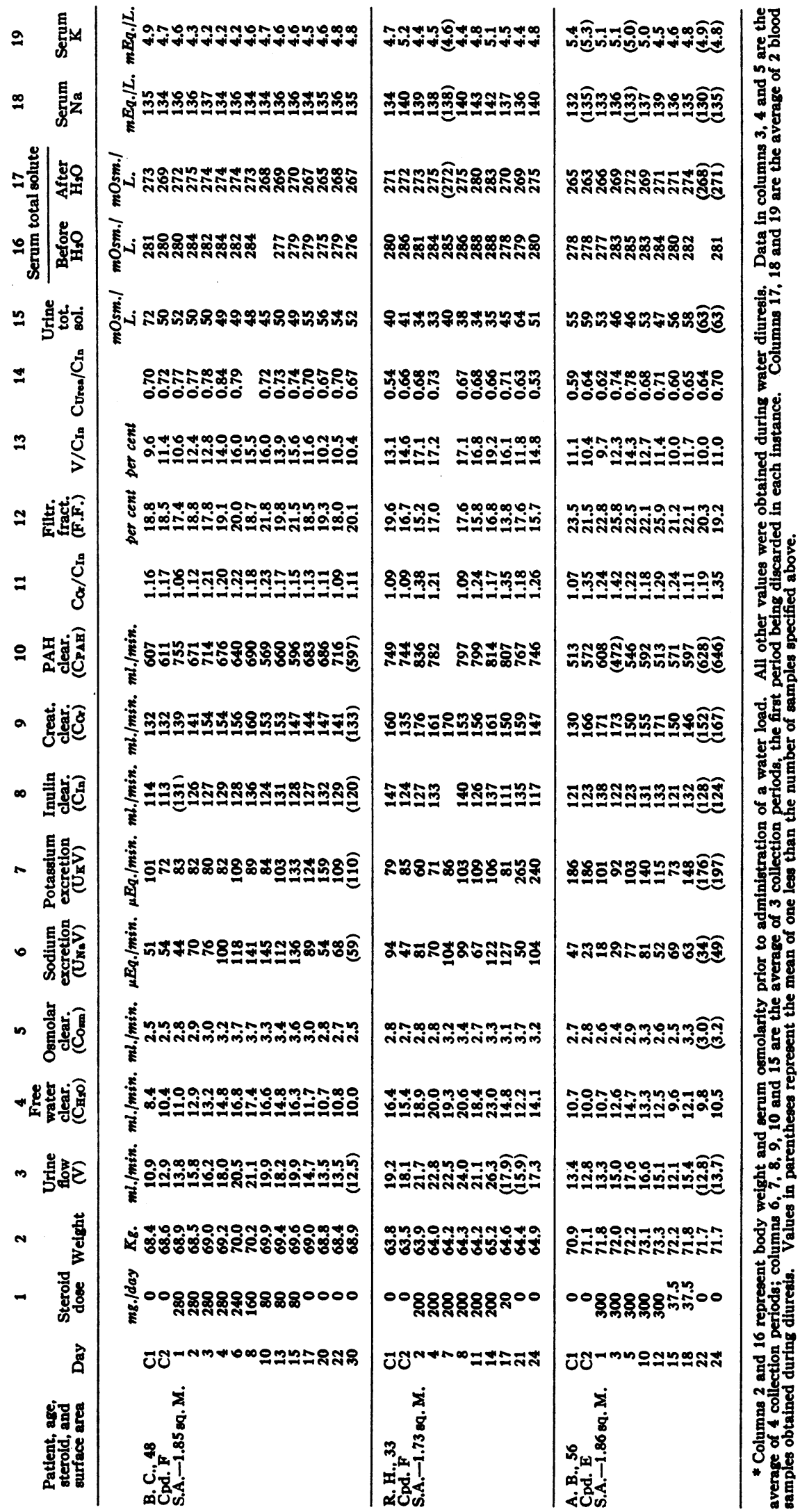


30 to $50 \mathrm{ml}$. per hour for insensible loss. After the urine flow had reached a peak, four consecutive 20 to 30 minute collections were obtained by voluntary voiding." Venous blood samples were obtained at the midpoint of three of the four clearance periods. The data for urine flow, osmolal clearance and free-water clearance recorded in Table II are the average of all four collection periods. Only the last three periods were averaged to obtain mean values for clearances of inulin, para-aminohippurate and excretion rates of individual solutes. The first high-flow period was discarded in order to avoid washout errors during rising urine flow. Data for the last experiment on B.C. and the last two experiments on A.B. are based on only three urine collection periods, of which the last two were averaged to provide mean values for inulin clearance, para-aminohippurate clearance and excretion rates of individual solutes. In R.H. and A.B. the water loading was performed daily throughout the period of study, regardless of whether clearances were being measured.

The maximal urine flow following a water load rose during steroid administration in each subject (Table II). In B.C. the control rates were 10.9 and $12.9 \mathrm{ml}$. per min. 'The rate increased progressively to $21.1 \mathrm{ml}$. per min. on the eighth day of hydrocortisone (Figure 1). In R.H. flow increased from control values of 19.2 and 18.1 to $26.3 \mathrm{ml}$. per min. on the fourteenth day, the last on which hydrocortisone was given in high doses. The oldest subject studied, A.B., had the smallest increase, from controls of 13.4 and 12.8 to a peak of $17.6 \mathrm{ml}$. per min. on the fifth day of cortisone administration. ${ }^{5}$ There was no further rise in this subject despite continued administration of steroid. Maximal urine flow decreased soon after the steroid was discontinued, or the dose decreased to

4 To assess the completeness of voluntary voiding the variation in creatinine output was ascertained in each subject as suggested by Mills, Thomas, and Yates (11). In 114 clearance periods of 38 studies the average deviation of creatinine excretion in any single period from the day's mean was 3 per cent. In 112 periods the deviation from the mean was no greater than 8 per cent. In the other two periods, the deviations were 10 and 13 per cent.

5 A.B. was also the only subject who received oral cortisone. However very large increments in flow were observed in subjects receiving intramuscular cortisone (Table I).
TABLE III

Correlation coefficients $(r)$ and their significance $(p)$ for
\[ C_{H_{2} O} v s . U_{N a} V, C_{0 m} \text {, and weight, for } \] data shown in Figure 2

\begin{tabular}{|c|c|c|c|c|c|c|}
\hline & \multicolumn{2}{|c|}{ B. C. } & \multicolumn{2}{|c|}{ R. H. } & \multicolumn{2}{|c|}{ A. B. } \\
\hline & $r$ & $p$ & $r$ & $p$ & $r$ & $p$ \\
\hline $\begin{array}{c}\mathrm{U}_{\mathrm{Na}_{\mathrm{B}} \mathrm{V}} \\
\boldsymbol{v s .} \\
\mathrm{C}_{\mathrm{H}_{2} \mathrm{O}}\end{array}$ & .969 & $<.001$ & .896 & $\begin{array}{l}<.02 \\
>.01\end{array}$ & .886 & $\begin{array}{l}<.02 \\
>.01\end{array}$ \\
\hline $\begin{array}{l}C_{\text {Oam }} \\
\text { vs. } \\
C_{\mathrm{H}_{20}}\end{array}$ & .898 & $<.001$ & .716 & $\begin{array}{l}<.10 \\
>.05\end{array}$ & -.052 & $>.10$ \\
\hline $\begin{array}{c}\text { Weight } \\
\text { vs. } \\
\mathrm{C}_{\mathrm{H}_{2} \mathrm{O}}\end{array}$ & .917 & $<.001$ & .878 & $\begin{array}{l}<.01 \\
>.001\end{array}$ & .596 & $>.10$ \\
\hline
\end{tabular}

a maintenance amount. In all three subjects osmolal clearance changed only slightly, never increasing by more than $1.2 \mathrm{ml}$. per min. so that the change in urine flow was largely due to an increase in free-water clearance.

Although glomerular filtration rate $\left(\mathrm{C}_{\text {In }}\right)$ was somewhat higher during hormone administration in each subject, the differences were small. When the data for all three subjects were combined, the average of control observations (including studies on a maintenance dose) was $124.7 \mathrm{ml}$. per min. (standard error $\pm 2.3 \mathrm{ml}$. per min.) and the combined average of all studies during steroid administration (except on maintenance dose) was $130.0 \pm 1.2 \mathrm{ml}$. per min. $(p<0.05)$. The differences in filtration rate did not reach conventional levels of significance when the data for each subject were considered individually, or when studies on maintenance doses of steroid were grouped with those on higher doses. Since the rate of urine flow after water loading invariably rose during steroid administration and filtration rate usually increased the two changes were necessarily often associated. However, increase in urine flow did not parallel augmentation in $\mathrm{C}_{\mathrm{In}}$. Thus B.C. manifested a marked rise in $\mathrm{C}_{\text {In }}$ on the first day of steroid administration with little rise in flow and no rise in the fraction of filtered water excreted $\left(\mathrm{V} / \mathrm{C}_{\text {In }}\right)$. Thereafter his flow rate rose progressively with virtually no further change in $\mathrm{C}_{\text {In }}$. Moreover, after hydrocortisone was discontinued flow and $V / C_{\text {In }}$ fell almost to the range of the control period, while $\mathrm{C}_{\text {In }}$ remained above control values. In R.H. the initial rise in flow and 


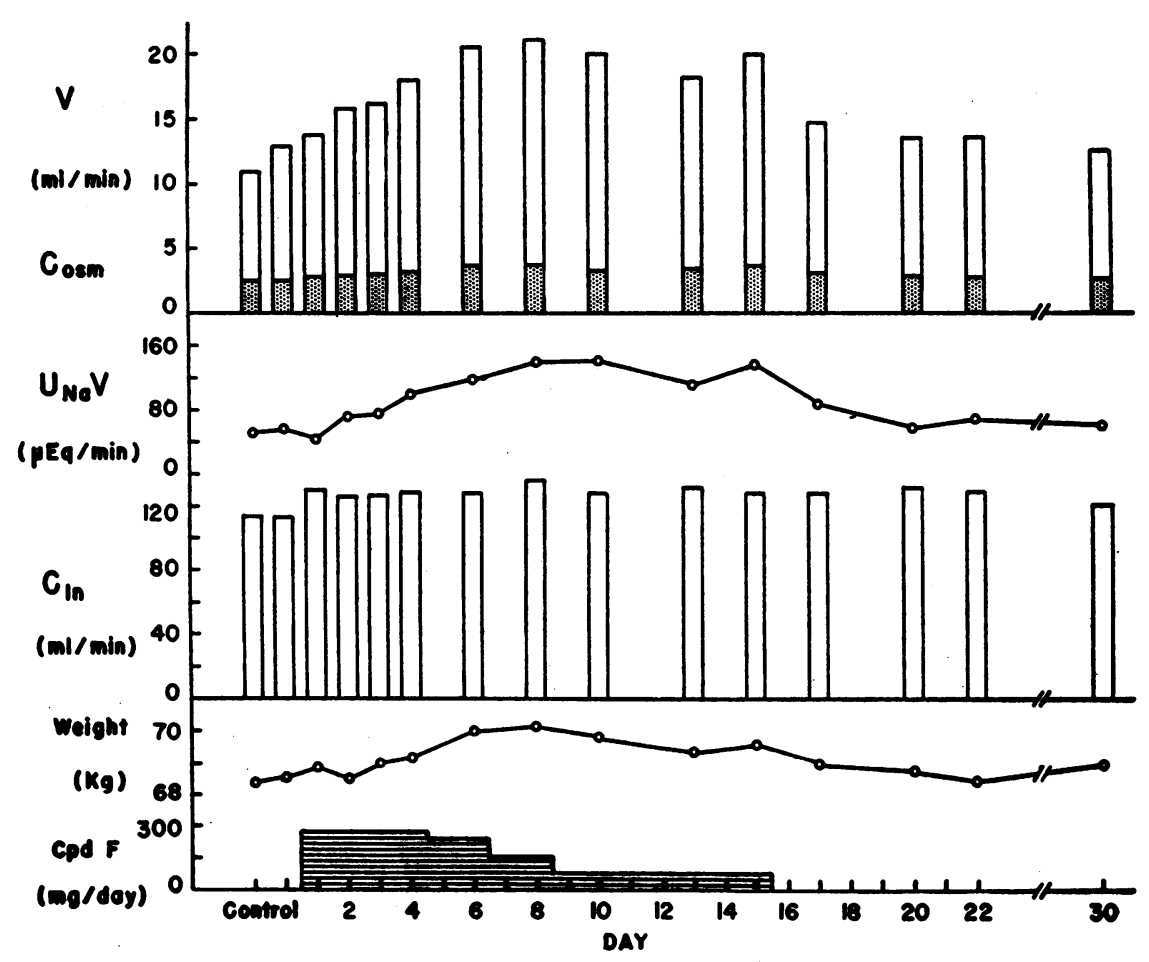

Fig. 1. Subject B.C.-Effects of Hydrocortisone on Urine Flow (V), Osmolar Clearance (Comm), Sodium Excretion ( $U_{\mathrm{Na}} \mathrm{V}$ ), Glomerular Filtration Rate ( $C_{\text {In }}$ ) and Weight, dURing Water DiUResis

At the top of the figure, $\mathrm{V}$ is shown by bars, the lower stippled portions of which represent $\mathrm{C}_{0 \leq \mathrm{m}}$, the clear areas, free water clearance $\left(\mathrm{C}_{\mathrm{H}_{2} \mathrm{O}}\right)$.

$\mathrm{V} / \mathrm{C}_{\text {In }}$ was unassociated with elevation of $\mathrm{C}_{\text {In }}$. In A.B. the highest rate of urine flow was observed on the fifth day of hydrocortisone administration when $\mathrm{C}_{\text {In }}$ was at control levels.

Effective renal plasma flow $\left(\mathrm{C}_{\mathrm{PAH}}\right)$ showed more random variation than $C_{I n}$. No consistent trend was observed in subjects B.C. or A.B. In R.H., the youngest subject, $\mathrm{C}_{\mathbf{P A B}}$ was consistently higher during steroid administration; during the control periods before and after steroid administration, his average renal plasma flow was $763 \pm 13 \mathrm{ml}$. per min. whereas it was $806 \pm 10 \mathrm{ml}$. per min. ( $p<0.05)$, while hormone was being given.

Endogenous creatinine clearance generally paralleled inulin clearance, although in individual experiments the ratio of creatinine to inulin clearance $\left(\mathrm{C}_{\mathrm{Or}} / \mathrm{C}_{\mathrm{In}}\right.$, Table II) ranged between 1.08 and 1.40. The average $C_{C_{r}} / C_{\text {In }}$ ratio was $1.21 \pm$ 0.02 during control studies and $1.18 \pm 0.02$ during steroid administration.

The data concerning urea clearance, which represent one period in each experiment, are presented in terms of the ratio to inulin clearance ( $\mathrm{C}_{\text {Urea }} / \mathrm{C}_{\text {In }}$, Table II). This expression minimizes errors due to bladder emptying. In each subject there was an increase in the ratio of urea to inulin clearance during steroid therapy. In subject B.C., for whom the most extensive data are available, $\mathrm{C}_{\text {Urea }} / \mathrm{C}_{\text {In }}$ averaged $0.69 \pm 0.01$ during control studies and $0.77 \pm 0.01$ during steroid administration $(p<0.01)$. The serum urea concentration was not affected by steroid administration.

In addition to the increase in free-water clearance $\left(\mathrm{C}_{\mathrm{H}_{2} \mathrm{O}}\right)$ during steroid administration there was an increase in sodium excretion $\left(U_{N a} V\right)$, osmolal clearance $\left(\mathrm{C}_{\mathrm{Osm}}\right)$, and the body weight. When hormone administration was discontinued, $\mathrm{C}_{\mathrm{H}_{2} \mathrm{O}}$ fell promptly. However, $\mathrm{U}_{\mathrm{Na}} \mathrm{V}, \mathrm{C}_{\mathrm{Osm}}$, and weight all remained elevated above pre-steroid control values in subjects R.H. and A.B.; so that there was no correlation between these variables and water excretion during the period after steroid 


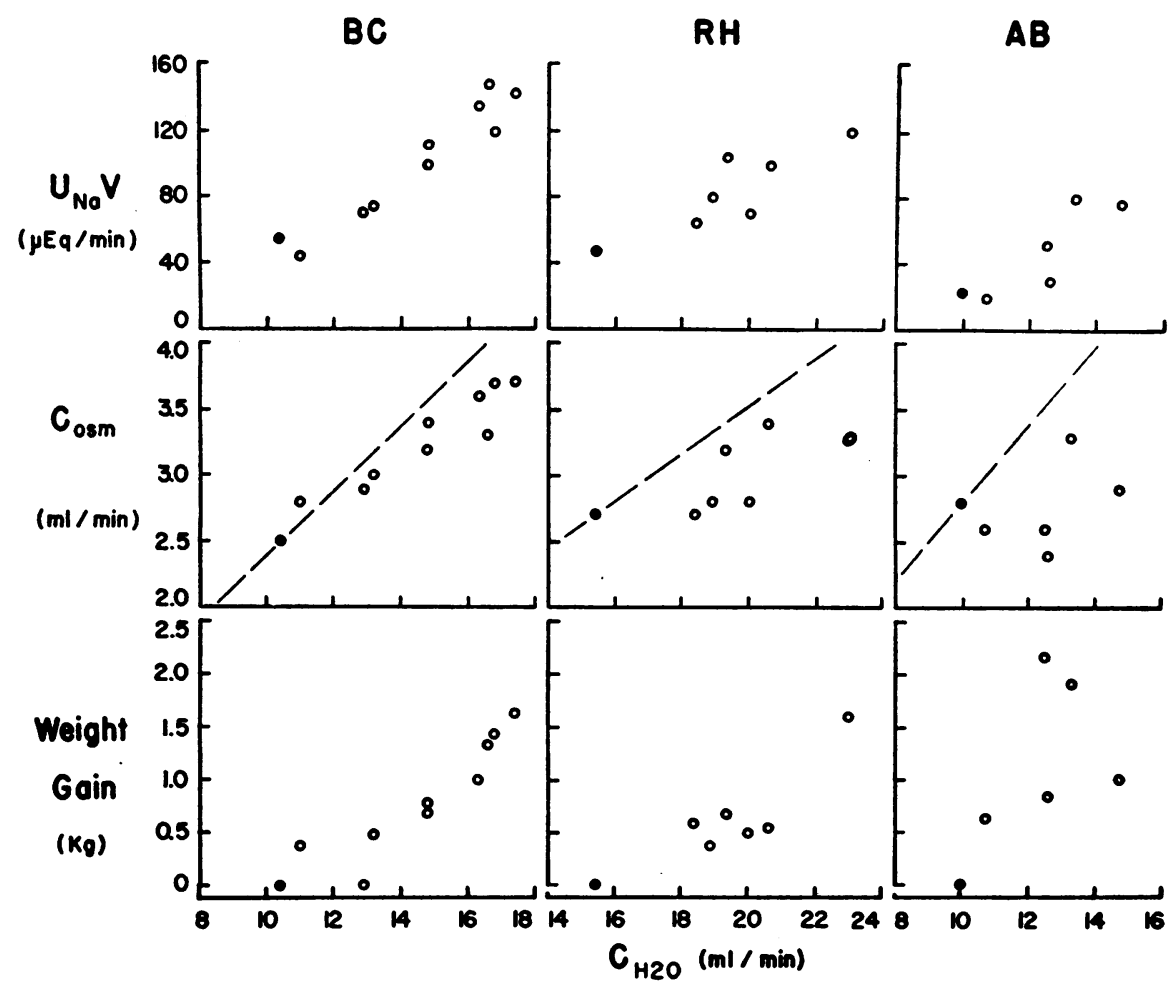

Fig. 2. The Relationship between Free Water Clearance $\left(\mathrm{C}_{\text {ho }}\right.$ ) and Sodium Excretion ( $U_{\text {neV }}$ ), Osmolar Clearance (Cosm) and Weight Gain is Shown in Scatter Diagrams for Subjects B.C., R.H. and A.B.

Closed circles represent the second of two control determinations; open circles represent values obtained on high doses of steroids. The dashed lines on the charts showing $\mathrm{C}_{\mathrm{O} s \mathrm{~m}}$ vs. $\mathrm{C}_{\mathrm{H}_{2} \mathrm{O}}$ indicate the relationship that would exist if urinary dilution remained at the control value. Except for one period in B.C. all points during steroid administration fall to the right of the line, indicating a urine more dilute than the control.

was discontinued. On the other hand, when the values for $\mathrm{U}_{\mathrm{Na}} \mathrm{V}, \mathrm{C}_{\mathrm{Osm}}$, and weight obtained just before and during steroid administration are plotted against $\mathrm{C}_{\mathrm{H}_{2} \mathrm{O}}$ (Figure 2) there is a significant correlation between $\mathrm{U}_{\mathrm{Na}} \mathrm{V}$ and $\mathrm{C}_{\mathrm{H}_{2} \mathrm{O}}$ in all three subjects and between weight and $\mathrm{C}_{\mathrm{H}_{2} \mathrm{O}}$ in two subjects (Table III). The changes in $\mathrm{C}_{\text {osm }}$ were relatively smaller than the changes in $\mathrm{C}_{\mathrm{H}_{2} \mathrm{O}}$ so that as urine flow increased, the urine became somewhat more dilute in each subject (Figure 2). The rate of potassium excretion showed little change during steroid administration and could not be correlated with any of the other variables measured. Serum electrolyte concentrations also showed little change.

Serum osmolarity varied between 275 and 288 mOsm. per L. before water administration in individual experiments and fell by 5.5 to 14.5
mOsm. per L. after water loading. The changes during steroid administration were of the same magnitude as in the control studies and the mean decrease in all experiments was $10.4 \mathrm{mOsm}$. per L. or 3.7 per cent of the initial value. This is approximately the change that is to be expected if the water load were evenly distributed throughout the total body water $(12,13)$. The expansion of plasma volume consequent to water loading, as reflected by change in hemoglobin, hematocrit and serum protein concentration, also appeared to be uninfluenced by steroid administration.

\section{Group II. Acute response to intravenous infusion of hydrocortisone}

The acute effects of an intravenous infusion of hydrocortisone were studied in four patients with 


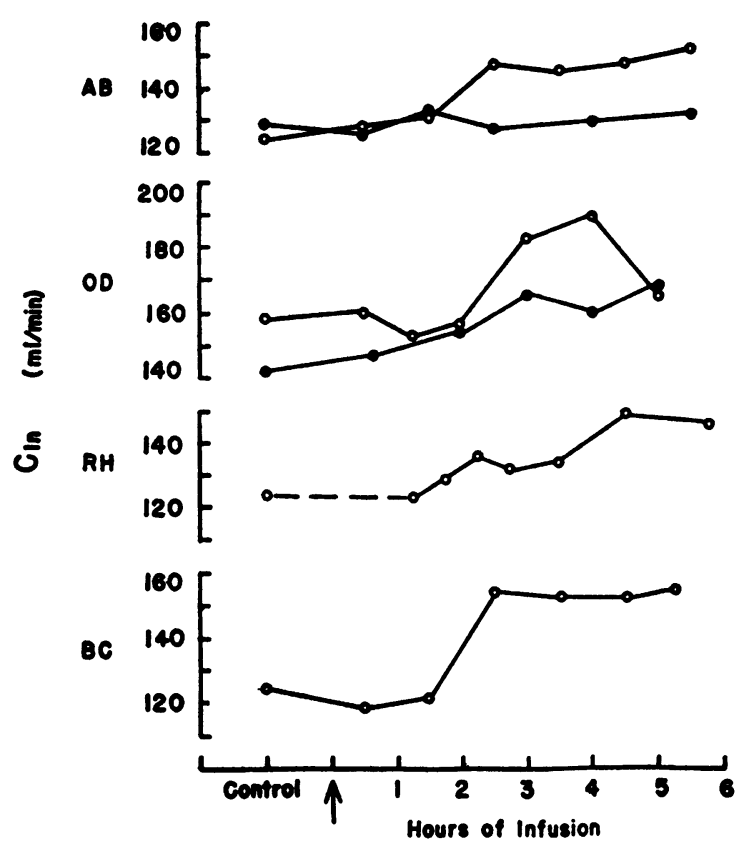

Fig. 3. Changes in Glomerular Filtration Rate ( $\mathrm{C}_{\text {In }}$ ) during Hydrocortisone (Open Circles) and Control Infusions (Closed Circles)

In Subject R.H., $C_{1 n}$ was not measured until one-half hour after hydrocortisone infusion was begun. The preinfusion value in this subject was obtained from a control study done $\mathbf{7 2}$ hours previously.

chronic skin disease, but otherwise healthy, while they were receiving a salt-poor diet (three were also the subjects of the studies in Group I-B). An oral water load was established and maintained as in the serial studies. Two hundred $\mathrm{mg}$. of hydrocortisone dissolved in $40 \mathrm{ml}$. of 50 per cent alcohol were diluted to between 1090 and $1340 \mathrm{ml}$. with 5 per cent glucose in water and infused at a rate of 3 to $4 \mathrm{ml}$. per minute. The volume of fluid infused was included in the calculation of water load maintenance. Control observations of water diuresis were made just before the steroid infusion was begun, except in R.H. In this subject the hydrocortisone infusion was given on the first day of the serial study of the effect of prolonged oral steroid administration. In B.C. and A.B. the infusions were given at the end of the post-steroid control period of the serial studies. In A.B. the effect of an infusion containing 20 $\mathrm{ml}$. of 95 per cent alcohol in $1050 \mathrm{ml}$. of 5 per cent glucose in water and in O.D. the effect of an infusion of $1050 \mathrm{ml}$. of 5 per cent glucose in water were also determined to provide additional control observations. Urine collections and venous blood samples were obtained at 20 to 60 -minute intervals.

A single hydrocortisone infusion had no consistent effect on maximal water diuresis (Table IV, Figure 3). A consistent increase in $\mathrm{C}_{\text {In }}$ was observed in each subject (Figure 3 ), beginning during the third hour of infusion. This increase varied between 12 and 27 per cent of the preinfusion values. During a control infusion of glucose and water alone, there was a rise in $\mathrm{C}_{\text {In }}$ in subject O.D., but a similar infusion did not affect filtration rate in subject A.B. There was no consistent change in $\mathrm{C}_{\mathrm{Cr}_{\mathrm{r}}} / \mathrm{C}_{\mathrm{In}}$ following hydrocortisone infusion. $\mathrm{C}_{\mathbf{P A B}}$ rose concurrently with $\mathrm{C}_{\text {In }}$. The $C_{\text {Urea }} / C_{\text {In }}$ ratio did not rise although serum urea values decreased progressively during the infusion.

Changes in sodium and potassium excretion were small. Sodium excretion fell from values of 49 to $75 \mu \mathrm{Eq}$. per min. to 15 to $35 \mu \mathrm{Eq}$. per min. during the last part of the hydrocortisone infusion. Potassium excretion was usually slightly higher during the last part of the hydrocortisone infusion than during the first two hours of infusion or during control periods. Serum potassium remained constant, while serum sodium sometimes showed a small decrease. In several experiments, both with and without hydrocortisone, there was a fall in urine flow despite maintenance of the water load. This decrease included a fall in both freewater clearance and osmolal clearance, although the fall in $\mathrm{C}_{\mathrm{H}_{2} \mathrm{O}}$ was proportionately somewhat greater, so that urine osmolality showed a slight rise.

\section{DISCUSSION}

Augmentation of the maximal urine flow during water diuresis was observed in each of nine subjects who were maintained on large doses of adrenocortical hormone. This change must have resulted from an increased rate of glomerular filtration, a decrease in tubular reabsorption of water, or both. ${ }^{\circ}$

- Secretion of water by the tubules (14) could also have been operative, but there is no clear evidence that such secretion occurs. On the other hand there is strong indirect evidence that free-water is made available for excretion, not by tubular secretion, but by reabsorption of solute from isotonic tubular fluid (15). Changes in the rate of absorption of water from the intestine would not account for the observed changes in maintained water diuresis, which is little influenced by increasing the magnitude of the water load either orally or parenterally. 


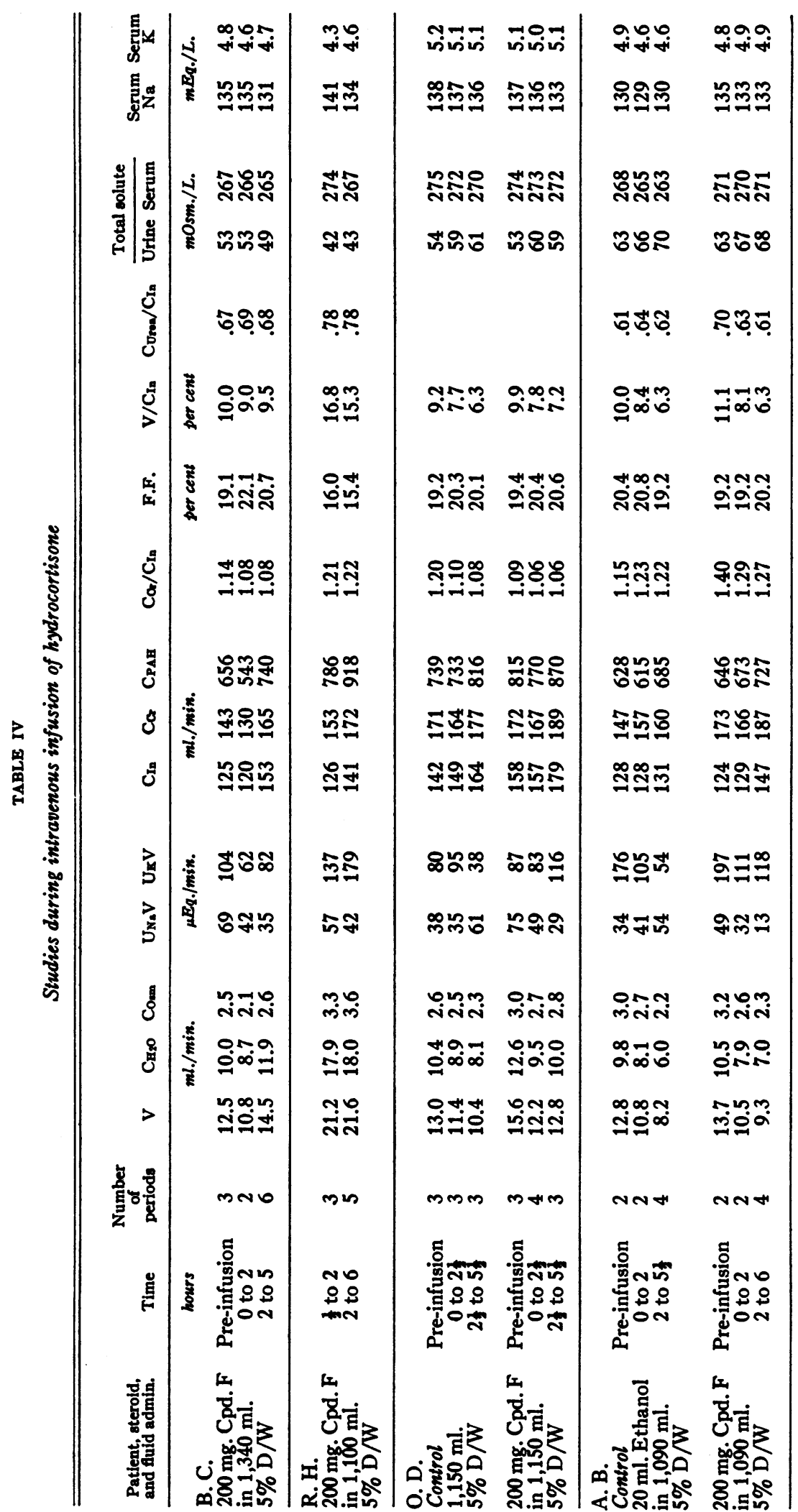


An increase in glomerular filtration rate during prolonged cortisone or corticotrophin administration has been reported by several observers (1618). The changes in filtration rate noted during continued hormone administration in the present study do not appear to account for the observed changes in water excretion. Thus, a striking increase in filtration rate occurred during single infusions of hydrocortisone, without augmentation of the rate of water diuresis. Furthermore, during prolonged oral administration of hydrocortisone or cortisone, changes in filtration rate were small, with large changes in the maximal rate of urine flow which could be dissociated temporally from the effect of glomerular filtration rate.

The increase in urine flow during prolonged oral steroid administration was usually accompanied by an increase in total solute excretion. Such an increase in urinary solute is known to augment the diuresis resulting from administration of large water loads (14, 15, 19-22). Moreover, when the magnitude of diuresis in water-loaded subjects is enhanced by increasing the solute load, the concentration of total solute characteristically rises $(22,23)$. On the other hand the rise in solute output during steroid administration, when it occurred, was so small compared to the increase in urine flow that solute concentration fell. Hence the changes in free water clearance observed cannot be explained on the basis of an increase in solute load with a fixed "maximal urinary diluting power." When dietary sodium was restricted, the increase in urine flow during steroid administration was regularly accompanied by an increase in sodium output ${ }^{7}$ (Figure 2). This observation is consistent with the possibility that augmentation of water diuresis might have been related to an increase in the rate of sodium excretion (20). However, this relationship was not regularly observed when the diet was varied (Table I, W.H.

7 Although most observers have described a decrease in sodium excretion and a rise in potassium excretion during the administration of cortisone, hydrocortisone, or corticotrophin, the appearance of such changes and their magnitude appear to depend upon the conditions of the experiment (24-27). For example, Liddle, Pechet, and Bartter (26) have noted that in dogs the rate of sodium excretion may rise, fall, or remain constant when adrenocortical hormones are given, depending upon the relative magnitudes of the changes in glomerular filtration rate and sodium reabsorption. and G.S.). Hence, changes in flow could not always be related to change either in the excretion of sodium or of total solute.

Cortisone and hydrocortisone might affect water diuresis by some form of antagonism to antidiuretic hormone (ADH). Excess $\mathrm{ADH}$ activity has been proposed as the cause of failure of water diuresis in adrenal insufficiency (4). The evidence is based on bioassays $(1,28)$ of blood and urine performed by techniques which have been seriously challenged (29). Certainly in the waterloaded normal subject who is in a state of "physiologic diabetes insipidus" it is reasonable to assume that no circulating $\mathrm{ADH}$ is present. The validity of this assumption is supported by the observation that in such subjects the administration of alcohol, a powerful inhibitor of $\mathrm{ADH}$, does not enhance urine flow (30), an observation that we have confirmed in a number of subjects, including B.C. of the present study. Therefore, the increased water diuresis observed during steroid administration cannot be ascribed to further inhibition of $\mathrm{ADH}$. We have also observed that the antidiuretic response to small doses of Pitressin ${ }^{\circledR}$ (15 milli-units intravenously) administered during water diuresis is not altered during cortisone administration, so that there is probably no change in the sensitivity of the kidney to ADH.

If the increase in maximal rate of water diuresis during prolonged steroid administration cannot be ascribed to changes in glomerular filtration rate, solute excretion or an effect on $\mathrm{ADH}$, it must be due to an intrinsic change in the renal tubular handling of water. Moreover, the increase is chiefly in free-water clearance. Hence the change must involve the mechanism for formation of "free" water, an operation which is believed to occur in the distal tubule (31-33). In the absence of $\mathrm{ADH}$, the magnitude of free-water clearance is dependent upon the volume of isotonic or possibly hypotonic fluid (34), delivered from the proximal segments, which is rendered free of solute in the distal tubules. ${ }^{8}$ According to this schema, the

8 Additional reabsorption of water $\left(\mathrm{T}^{\mathrm{c}}{ }_{\mathrm{H}_{3} \mathrm{O}}\right)$ is believed to take place at a still more distal site, presumably the collecting ducts (15). When $\mathrm{ADH}$ effect is maximal the distal tubular fluid remains isotonic, so that the further abstraction of water in the collecting ducts results in the formation of a hypertonic urine. Furthermore it appears that $T^{c} \mathrm{H}_{2} \mathrm{O}$ is operative even under conditions of 
increase in urine flow and free-water clearance observed during steroid administration could only have been the result of a decrease in proximal solute and water reabsorption, with increased delivery of isotonic fluid to the distal system and increased distal reabsorption of solute without water.

The hypothesis that "free" water is formed in the distal tubule does not require that all of the fluid delivered from the proximal system must be excreted or even delivered to the collecting tubules during water diuresis. Such complete excretion would require absolute impermeability of the distal cells to water in the absence of $\mathrm{ADH}$ and free permeability when $\mathrm{ADH}$ effect is maximal. It is perhaps more reasonable to suppose that the distal tubular epithelium is always partially permeable to water (33) and that $\mathrm{ADH}$ acts to increase the rate of movement of water in response to the concentration gradient established by prior solute reabsorption. Koefoed-Johnson and Ussing (37) have shown that when such an osmotic gradient is established across a piece of isolated frog skin, there is always a net movement of water, but that this movement is more rapid when posterior pituitary extracts are added to the preparation. They suggest that the action of the posterior pituitary extract is to increase the size. and/or number of pores in this membrane. If a similar mechanism obtains in the kidney, the increase in free-water clearance during steroid administration could be ascribed to diminution in the permeability of the cell membranes to water. The same rate of solute reabsorption would lead to less water reabsorption and the urine would be more dilute. Such a change might affect all the cells of the renal tubules; certainly localization of the site of action to the distal tubule has not been demonstrated. Lewis (38) has suggested that the failure of water diuresis in adrenal insufficiency and its correction by cortisone administra-

water diuresis (35) so that the amount of free-water actually being formed in the distal system is probably larger than the amount of free-water excreted in the urine by about $5 \mathrm{ml}$. per min., the maximum value of $\mathrm{T}^{\mathbf{c}}{ }_{\mathrm{H}_{2} \mathrm{O}}$ in normal man (36). If this moiety of water reabsorption were reduced during steroid administration then part of the change observed in free-water clearance could be explained. However, $\mathrm{T}^{\mathrm{c}} \mathrm{H}_{2} \mathrm{O}$, measured in the hydropenic state during mannitol diuresis, was not altered in one patient whom we studied before and after seven days of intensive cortisone therapy. tion may be due to inability of the distal tubule to reabsorb solute in excess of water unless an adequate supply of steroid is present. Our findings in normal subjects do not bear directly on this problem, and further studies in patients with adrenal insufficiency are needed.

The augmentation of urine flow and free-water clearance observed during steroid administration may therefore be ascribed to either or both of the following: 1) an increased delivery of solute to the distal tubule with increased reabsorption of solute in this area, 2) a decrease in osmotic permeability to water, so that less water leaves the tubular lumen in response to the osmotic gradient established by solute reabsorption.

The striking changes observed in free-water clearance provide additional evidence against the concept of a relatively constant value for this function $(15,19,31-33)$. Other data indicate that an increase in solute excretion during water diuresis may be accompanied by augmentation of free-water clearance $(20-22,34)$. A fall in freewater clearance associated with declining solute excretion regularly accompanies the decrease in diuresis which occurs when a water load is maintained in seated subjects $(20,23)$. Variations in diet which are associated with change in the daily load of solute excreted, as well as with change in glomerular filtration rate, also influence the magnitude of water diuresis and of free-water clearance in normal man (22). Striking augmentation of maximal water diuresis occurs in the dog and the seal when an increase in glomerular filtration is induced $(39,40)$. However, it appears that the administration of adrenocortical hormone, in large doses continued over a number of days, differs from all other procedures known to influence the magnitude of free-water clearance in that its effect does not depend upon change in antidiuretic hormone, glomerular filtration rate, or renal excretion of solute.

During water diuresis the tubular reabsorption of urea is thought to result chiefly from passive back-diffusion in the proximal tubule. The rise in urea/inulin clearance ratio observed in the present studies therefore suggests either a decrease in the proportion of glomerular filtrate reabsorbed in the proximal segment, or a decrease in the permeability of this segment to urea. 


\section{SUMMARY}

The effects of large doses of cortisone and hydrocortisone on water diuresis and renal function in man have been examined. The rate of urine flow observed during a maintained water load was regularly increased greatly during steroid administration irrespective of changes in the dietary intake and renal excretion of sodium salts.

Serial studies in subjects on a salt-poor diet demonstrated an increase in maximal urine flow and in free-water clearance. The increased excretion of water was usually but not invariably accompanied by a small increase in sodium excretion, a gain in body weight, and sometimes by an increase in total solute excretion. The small rise in glomerular filtration rate noted during steroid administration did not parallel the increase in maximal urine flow.

A single intravenous infusion of hydrocortisone regularly produced an increase in glomerular filtration rate, but without a consistent increase in the diuretic response to water loading.

The observations indicate that continued administration of steroid in large doses influences the renal tubular reabsorption of water. It is suggested that more free water is made available for excretion because of 1) a redistribution of solute reabsorption between proximal and distal systems or 2) an alteration in the permeability of the renal tubular epithelium to water.

\section{ACKNOWLEDGMENT}

The technical assistance of Miss Elsie Rossmeisl, Miss Regina McLean, Miss Helen Alpert, Miss Miriam Halpin, Mrs. Janet Riley and Miss Ellen Vaznelis is gratefully acknowledged.

Financial assistance for procurement of reprints was provided by the Gray Pharmaceutical Company, Newton, Massachusetts.

\section{REFERENCES}

1. Slessor, A., Studies concerning the mechanism of water retention in Addison's disease and in hypopituitarism. J. Clin. Endocrinol., 1951, 11, 700.

2. Oleesky, S., and Stanbury, S. W., Effect of oral cortisone on water diuresis in Addison's disease and hypopituitarism. Lancet, 1951, 2, 664.

3. Garrod, O., and Burston, R. A., The diuretic response to ingested water in Addison's disease and panhypopituitarism and the effect of cortisone thereon. Clin. Sc., 1952, 11, 113.
4. Gaunt, R., Birnie, J. H., and Eversole, W. J., Adrenal cortex and water metabolism. Physiol. Rev., 1949, 29, 281.

5. Rosenbaum, J. D., Ferguson, B. C., Davis, R. K., and Rossmeisl, E. C., The influence of cortisone upon the diurnal rhythm of renal excretory function. J. Clin. Invest., 1952, 31, 507.

6. Hare, R. S., Endogenous creatinine in serum and urine. Proc. Soc. Exper. Biol. \& Med., 1950, 74, 148.

7. Young, M. K., Jr., and Raisz, L. G., An anthrone procedure for determination of inulin in biological fluids. Proc. Soc. Exper. Biol. \& Med., 1952, 80, 771.

8. Goldring, W., and Chasis, H., Hypertension and $\mathrm{Hy}-$ pertensive Disease. New York, The Commonwealth Fund, 1944, p. 203.

9. Van Slyke, D. D., and Cullen, G. E., The determination of urea by the urease method. J. Biol. Chem., 1916, 24, 117.

10. Rosenbaum, J. D., Davis, R. K., and Ferguson, B. C., The influence of cortisone on water diuresis in man. J. Clin. Invest., 1951, 30, 668.

11. Mills, J. N., Thomas, S., and Yates, P. A., Assessment of voluntary bladder emptying in man. $J$. Physiol., 1955, 129, 408.

12. Leaf, A., Chatillon, J. Y., Wrong, O., and Tuttle, E. P., Jr., The mechanism of the osmotic adjustment of body cells as determined in vivo by the volume of distribution of a large water load. J. Clin. Invest., 1954, 33, 1261.

13. Wynn, V., A metabolic study of acute water intoxication in man and dogs. Clin. Sc., 1955, 14, 669.

14. Brodsky, W. A., and Rapoport, S., The mechanism of polyuria of diabetes insipidus in man. The effect of osmotic loading. J. Clin. Invest., 1951, 30, 282.

15. Wesson, L. G., Jr., and Anslow, W. P., Jr., Effect of osmotic and mercurial diuresis on simultaneous water diuresis. Am. J. Physiol., 1952, 170, 255.

16. Burnett, C. H., The actions of ACTH and cortisone on renal function in man in Trans. Second Conf. on Renal Function (1950). New York, Josiah Macy, Jr., Foundation, 1951, p. 106.

17. Levitt, M. F., and Bader, M. E., Effect of cortisone and $\mathrm{ACTH}$ on fluid and electrolyte distribution in man. Am. J. Med., 1951, 11, 715.

18. Earle, D. P., Alexander, J. D., Farber, S. J., and Pellegrino, E. D., Observations on the relation of renal function changes to the electrolyte and glycosuric effects of ACTH in Proc. of the Second Clinical ACTH Conference, J. R. Mote, Ed., Philadelphia, Blakiston Co., 1951, Vol. 1, p. 139.

19. Ladd, M., Renal excretion of sodium and water in man as affected by prehydration, saline infusion, Pitressin and thiomerin. J. Applied Physiol., 1952, 4, 602 .

20. Rosenbaum, J. D., Nelson, W. P., III, Strauss, M. B., Davis, R. K., and Rossmeisl, E. C., Variation in the diuretic response to ingested water related to 
the renal excretion of solutes. J. Clin. Invest., 1953, 32, 394.

21. Welt, L. G., Young, D. T., Thorup, O. A., Jr., and Burnett, C. H., A study of renal tubular phenomena under the influence of a carbonic anhydrase inhibitor. J. Clin. Invest., 1954, 33, 972.

22. Kleeman, C. R., Epstein, F. H., and White, C., The effect of variations in solute excretion and glomerular filtration on water diuresis. J. Clin. Invest., 1956, 35, 749.

23. Rosenbaum, J. D., and Seifer, H. W., Unpublished observations.

24. Seldin, D. W., Welt, L. G., and Cort, J., The effect of pituitary and adrenal hormones on the metabolism and excretion of potassium. J. Clin. Invest., 1951, 30, 673.

25. Thorn, G. W., Jenkins, D., and Laidlaw, J. C., The adrenal response to stress in man. Rec. Prog. Hormone Research, 1953, 8, 171.

26. Liddle, G. W., Pechet, M. M., and Bartter, F. C., Enhancement of biological activities of corticosteroids. by substitution of halogen atoms in $9 \alpha$ position. Science, 1954, 120, 496.

27. Knight, R. P., Jr., Kornfeld, D. S., Glaser, G. H., and Bondy, P. K., Effects of intravenous hydrocortisone on electrolytes of serum and urine in man. J. Clin. Endocrinol., 1955, 15, 176.

28. Lloyd, C. W., and Lobotsky, J., Serum antidiuretic substances and urinary corticosteroid in the human. J. Clin. Endocrinol., 1950, 10, 318.

29. Van Dyke, H. B., Adamsons, K., Jr., and Engel, S. L., Aspects of the the biochemistry and physiology of the neurohypophyseal hormones. Rec. Prog. Hormone Research, 1955, 11, 1.

30. Kleeman, C. R., Rubini, M. E., Lamdin, E., and Ep- stein, F. H., Studies on alcohol diuresis. II. The evaluation of ethyl alcohol as an inhibitor of the neurohypophysis. J. Clin. Invest., 1955, 34, 448.

31. Smith, H. W., The Kidney: Structure and Function in Health and Disease. New York, Oxford University Press, 1951, pp. 306-331.

32. Smith, H. W., Renal excretion of sodium and water. Federation Proc., 1952, 11, 701.

33. Smith, H. W., Principles of Renal Physiology. New York, Oxford University Press, 1956, pp. 108-114.

34. de Wardener, H. E., and del Greco, F., The influence of solute excretion rate on the production of a hypotonic urine in man. Clin. Sc., 1955, 14, 715.

35. Berliner, R. W., and Davidson, D. G., Production of hypertonic urine in the absence of pituitary antidiuretic hormone. J. Clin. Invest., 1956, 35, 690.

36. Zak, G. A., Brun, C., and Smith, H. W., The mechanism of formation of osmotically concentrated urine during the antidiuretic state. J. Clin. Invest., 1954, 33, 1064.

37. Koefoed-Johnson, V., and Ussing, H. H., The contributions of diffusion and flow to the passage of $\mathrm{D}_{2} \mathrm{O}$ through living membranes. Effect of neurohypophyseal hormone on isolated anuran skin. Acta physiol. Scandinav., 1953, 28, 60.

38. Lewis, A. A. G., in The Suprarenal Cortex, Yoffey, J. M., Ed., New York, Academic Press, 1953, p. 198.

39. Ludemann, H., Raisz, L. G., and Wirz, H., Filtration rate and water diuresis in the dog. Am. J. Physiol., 1951, 166, 416.

40. Ladd, M., Raisz, L. G., Crowder, C. H., Jr., and Page, L. B., Filtration rate and water diuresis in the seal, Phoca vitulina. J. Cell. \& Comp. Physiol., 1951, 38, 157. 